\title{
Spectrophotometric determination of a substance trifusol in a veterinary suppository
}

\author{
K. H. Klosova ${ }^{\mathrm{B}, \mathrm{D}}$ iD, K. P. MiedviedievaC,D iD, S. O. Vasiuk ${ }^{\mathrm{E}, \mathrm{F}}$ iD, I. V. Bushuieva ${ }^{\star A, E}$ iD \\ Zaporizhzhia State Medical University, Ukraine
}

A - research concept and design; B - collection and/or assembly of data; C - data analysis and interpretation; D - writing the article; $\mathrm{E}$ - critical revision of the article; $\mathrm{F}$ - final approval of the article

The purpose of the work was to develop of a method for the quantitative determination of piperidinium 2-[5-(2-furyl)-4-phenyl-1,2,4triazol-3-ylthio] acetate (trifuzol) as part of a dosage form - an effervescent intrauterine suppository using spectrophotometry in the ultraviolet region spectrum and its validation according to State Pharmacopoeia of Ukraine.

Materials and methods. The study was used a working standard sample of trifuzol, intrauterine effervescent veterinary suppositories, $1.0 \mathrm{~g}$ of trifuzol, as a solvent - purified water. Analytical equipment: Specord 200 spectrophotometer, electronic scales ABT-120-5DM, ultrasonic bath ELMASONICE $60 \mathrm{H}$, class A measuring dishes. Method of spectrophotometric analysis was used.

Results. A spectrophotometric method has been developed and validated for the quantitative determination of trifuzol in a dosage form - an intrauterine effervescent veterinary suppository, based on measuring the absorption of an aqueous solution of the drug at $278 \mathrm{~nm}$.

The methodology tally the requirements of State Pharmacopoeia of Ukraine for such validation characteristics as specificity, linearity, precision, correctness, and robustness. The analysis of the predicted total uncertainty of the analysis was showed the reproducibilityof the method and the possibility of its application in other laboratories.

Conclusions. A method for the quantitative determination of trifuzol in the composition of the dosage form, an effervescent intrauterine suppository, according to the requirements of State Pharmacopoeia of Ukraine, was developed and validated. It was proved that according to such validation characteristics as linearity, specificity, precision, correctness, and robustness, the technique is correct.

\section{Спектрофотометричне визначення трифузолу субстанції у ветеринарному супозиторії}

\section{К. Г. Кльосова, К. П. Мєдвєдєва, С. О. Васюк, І. В. Бушуєва}

Мета роботи - розроблення методики кількісного визначення піперидиній 2-[5-(2-фрурил)-4-френіл-1,2,4-тріазол-3-ілтіо]ацетату (трифузолу) у складі лікарської форми - шипучого внутрішньоматкового супозиторію - з застосуванням спектрофотометрії в ультрафіолетовій області спектра та здійснення ії̈ валідації за ДФУ.

Матеріали та методи. У дослідженні використали робочий стандартний зразок трифузолу, внутрішньоматкові шипучі ветеринарні супозиторії, 1,0 г трифузолу, як розчинник - воду очищену. Аналітичне обладнання: спектрофотометр Specord 200, ваги електронні ABT-120-5DM, ультразвукова баня ELMASONICE 60 H, мірний посуд класу А. Застосували метод спектрофотометричного аналізу.

Результати. Розроблено та валідовано спектрофотометричну методику кількісного визначення трифузолу в лікарській формі внутрішньоматковому шипучому ветеринарному супозиторії, - що заснована на вимірюванні абсорбції водного розчину препарату при 278 нм.

Методика відповідає вимогам ДФУ за такими валідаційними характеристиками, як специфічність, лінійність, прецизійність, правильність і робастність. Аналіз прогнозованої повної невизначеності аналізу показав відтворюваність методики та можливість її застосування в інших лабораторіях.

Висновки. Розробили та здійснили валідацію методики кількісного визначення трифузолу у складі лікарської форми - шипучого внутрішньоматкового супозиторію - за вимогами ДФУ. Доведено, що за такими валідаційними характеристиками, як лінійність, специфічність, прецизійність, правильність і робастність методика є коректною.

Ключові слова: спектрофотометрія, трифузол, ветеринарний супозиторій, кількісне визначення.

Актуальні питання фрармацевтичної і медичної науки та практики. 2020. Т. 13, № 1(32). С. 46-50

ARTICLE

INFO

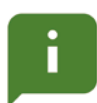

http:l/pharmed.

zsmu.edu.ualarticle/

view/198123
UDC $615.281 .8 \cdot 792 \cdot 615.454 \cdot 2 \cdot 661.158] .074: 543.42$

DOI: $10.14739 / 2409-2932.2020 .1 .198123$

Current issues in pharmacy and medicine: science and practice $2020 ; 13$ (1), 46-50

Key words: spectrophotometry, trifuzol, veterinary suppository, quantitative determination.

*E-mail: valery999@ukr.net

Received: 29.11.2019// Revised: 09.12.2019 // Accepted:16.12.2019 


\section{Спектрофотометрическое определение трифузола субстанции в ветеринарном суппозитории}

\section{К. Г. Клёсова, К. П. Медведева, С. А. Васюк, И.В.Бушуева}

Цель работы - разработка методики количественного определения пиперидиний 2-[5-(2-фурил)-4-френил-1,2,4-триазол-3-илтио] ацетата (трифузол) в составе лекарственной формы - шипучего внутриматочного суппозитория - с применением спектрофотометрии в ультрафиолетовой области спектра и проведение ее валидации согласно ГФУ.

Материалы и методы. В исследовании использованы рабочий стандартный образец трифузола, внутриматочные шипучие ветеринарные суппозитории, 1,0 г трифузола, как растворитель - вода очищенная. Аналитическое оборудование: спектрофотометр Specord 200, весы электронные ABT-120-5DM, ультразвуковая баня ELMASONICE 60 H, мерная посуда класса A. Применили метод спектрофотометрического анализа.

Результаты. Разработана и валидирована спектрофотометрическая методика количественного определения трифузола в лекарственной форме - внутриматочном шипучем ветеринарном суппозитории, - основанная на измерении абсорбции водного раствора препарата при 278 нм. Методика соответствует требованиям ГФУ по таким валидационным характеристикам, как специфичность, линейность, прецизионность, правильность и робастность. Анализ прогнозируемой полной неопределенности анализа показал воспроизводимость методики и возможность ее применения в других лабораториях.

Выводы. Разработана и проведена валидация методики количественного определения трифузола в составе лекарственной формы - шипучего внутриматочного суппозитория - согласно требованиям ГФУ. Доказано, что по таким валидационным характеристикам, как линейность, специфичность, прецизионность, правильность и робастность методика корректна.

Ключевые слова: спектрофотометрия, трифузол, ветеринарный суппозиторий, количественное определение.

Актуальные вопросы фрармацевтической и медицинской науки и практики. 2020. Т. 13, № 1(32). С. 46-50

Endometritis of different etiologies is the most common form of postnatal pathology in cows, which can take a mass character and cause significant economic damage to both the economy and the state as a whole. Against the background of the intensification of all branches of animal breeding, animal diseases involving damage to the sexual sphere prompted the search, creation, and improvement of existing medicines.

The use of the substance piperidinium 2-[5-(2-furyl)-4phenyl-1,2,4-triazole-3-iltio]acetate (trifusol), as an active substance in the composition of the effervescent intrauterine suppository, provides a sufficiently high therapeutic efficacy in the treatment, particularly of purulent postpartum cattle endometritis. Its use can improve the course of the pathological process and individual blood parameters $[5,6]$.

The development of new accurate and sensitive methods for quantifying trifusol in new dosage forms is an immediate need at the stage of ensuring proper quality control of drugs, in terms of safe, rational and effective therapy.

For other dosage forms, an express and easy-to-use method of trifusol quantitative determination have already been proposed [1]. Any analytical technique (including the technique of quality control of a particular drug) that may be proposed for inclusion in a normative document or by means of which official tasks will be performed (for example, official opinion on the quality of the object) should be validated [2-4]. Only a specific method for a specific dosage form can be validated.

\section{Aim}

Thus, the purpose of our work was to develop a method for quantitative determination of piperidinium 2-[5-(2-furyl)-4phenyl-1,2,4-triazole-3-iltio] acetate in the dosage form of effervescent intrauterine suppository using spectrophotometry in the ultraviolet region of the spectrum and its validation, according to the State Pharmacopoeia of Ukraine.

\section{Materials and methods}

Study objects, solvents and equipment. The objects of the investigation were intrauterine effervescent veterinary suppositories, $1.0 \mathrm{~g}$ of trifusol substance. The indicated dosage form was prepared extemporally according to the prescription [5].

Purified water was used as a solvent. As working standards of trifusol were used.

Analytical equipment: spectrophotometer Specord 200, electronic scales AVT-120-5DM, ultrasonic bath ELMASONICE $60 \mathrm{H}$, A class measuring ware.

General methodology for quantification of trifusol substance. Aliquot of trifusol $(0.050 \mathrm{~g})$ was placed in a measuring flask of $100.00 \mathrm{ml}$ and bring to the mark with purified water, and stirred. $1.00 \mathrm{ml}$ of the resulting solution was transferred to a measuring flask with a capacity of 25.00 $\mathrm{ml}$, and diluted with a solvent to the mark. Optical density was measured on the background of a compensation solution (purified water) at an analytical wavelength of $278 \mathrm{~nm}$.

\section{Results}

Method for quantitative determination of trifusol in a veterinary effervescent suppository for intrauterine use. 1 suppository was placed in a glass of $50 \mathrm{ml}$, added $25 \mathrm{ml}$ of distilled water and heated in an ultrasonic bath until the suppository was completely melted, then cooled and decanted in a measuring flask of $100.00 \mathrm{ml}$. This operation was repeated twice. The content of the flask was diluted with water to the mark and stirred thoroughly. $5.00 \mathrm{ml}$ of the resulting solution was transferred to a measuring flask with a capacity of $100.00 \mathrm{ml}$ and brought up to the mark with purified water. Optical density was measured against a solvent background at wavelength $278 \mathrm{~nm}$. At the same time, a $1.00 \mathrm{ml}$ of 0.05 $\%$ trifusol comparison solution was determined. The calculation of the active substance content was done according to 
Table 1. Uncertainty calculation of sample preparation for quantitative determination of trifuzol content in the intrauterine suppository

\begin{tabular}{|c|c|c|}
\hline Sample preparation operation & $\begin{array}{l}\text { Calculation formula } \\
\text { parameter }\end{array}$ & Uncertainty, $\%$ \\
\hline \multicolumn{3}{|l|}{ Test solution } \\
\hline Bringing up to volume in a measuring flask with a capacity of $100 \mathrm{ml}$ & 100 & 0.12 \\
\hline Taking aliquots dilution with a pipette in $5 \mathrm{ml}$ & 5 & 0.69 \\
\hline Bringing up to volume in a measuring flask with a capacity of $100 \mathrm{ml}$ & 100 & 0.12 \\
\hline Taking aliquots dilution with a pipette in $1 \mathrm{ml}$ & 1 & 0.74 \\
\hline Bringing up to volume in a measuring flask with a capacity of $25 \mathrm{ml}$ & 25 & 0.23 \\
\hline \multicolumn{3}{|l|}{ Reference solution } \\
\hline Taking a weighted amount of trifusol standard design sample & $m_{0}$ & $0.2 \mathrm{mg} / 50 \mathrm{mg} \cdot 100 \%=0.40$ \\
\hline Bringing up to volume in a measuring flask with a capacity of $100 \mathrm{ml}$ & 100 & 0.12 \\
\hline Taking aliquots dilution with a pipette in $1 \mathrm{ml}$ & 1 & 0.74 \\
\hline Bringing up to volume in a measuring flask with a capacity of $25 \mathrm{ml}$ & 25 & 0.23 \\
\hline
\end{tabular}

Table 2. Composition of excipients in intrauterine suppositories with trifusol

\begin{tabular}{|l|l|}
\hline Excipients & Quantity, $\mathbf{g}$ \\
\hline Sodium lauryl sulfate & 0.2 \\
\hline Polyethylene oxide mixture 1500 i $400-1: 9$ & Up to 20 \\
\hline
\end{tabular}

the usual formula.

Prediction of complete methodology uncertainty. To verify that the technique would be replicated in other laboratories, it was not enough just the results of the validation in one laboratory, the level of equipment which may be much higher than allowed by the State Pharmacopoeia of Ukraine. Calculations of the forecast of complete methodology uncertainty in accordance with the requirements of the State Pharmacopoeia of Ukraine were created specifically for this purpose. The total uncertainty of the analysis technique was based not only on the real total uncertainty of sample preparation but also on the maximum uncertainty for a specific equipment type $[7,8]$.

According to the requirements of the State Pharmacopoeia of Ukraine, uncertainty calculations were performed to the maximum permissible errors for measuring dishes, scales, and spectrophotometer as a final analytical operation in analysis $\left(\Delta_{\mathrm{FAO}}=0,70 \%\right)($ Table 1$)$.

It can be seen from Fig. 1 that the most significant uncertainty in sample preparation is introduced by operations 6 - taking a standard sample of trifusol, as well as 2, 4 and 8 taking aliquots by pipettes 1.00 and $5.00 \mathrm{ml}$. This distribution of uncertainty in sample preparation is quite typical for the quantitative determination of drugs.

Thus, the projected total uncertainty of the analysis results $\left({ }_{\triangle} A s=1,53 \%\right)$ does not exceed the critical value $\left({ }_{\max \Delta} A s=3.20\right)$, i.e. the technique will be reproducible and correct in other laboratories as well.

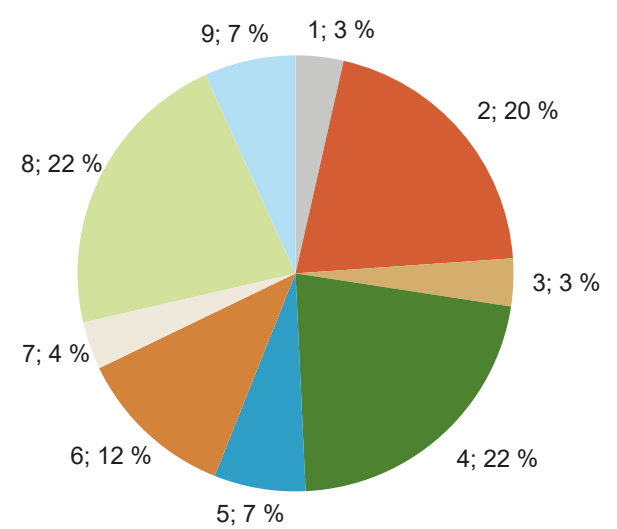

Fig. 1. Uncertainty distribution of sample preparation by operation for quantitative determination of trifusol in intrauterine suppository.

\section{Discussion}

The specificity of the technique was established by determining the effect of auxiliary substances (Table 2), which are part of the studied dosage form, on the results of trifusol quantitative determination. For this purpose, the placebo solution $\left(A_{\text {blank }}\right)$ absorption in purified water was measured in the concentrations of the corresponding prescription [5], making 3 measurements with cuvette extraction. At the same time the optical density of the comparison solution $\left(A_{\mathrm{st}}\right)$ was measured. The following was found out: $A_{\text {blank }}=0.0031 ; A_{\text {st }}$ 
Table 3. Main characteristics of linear dependence

\begin{tabular}{|l|l|l|l|}
\hline Data & Value & $\begin{array}{l}\text { Criteria (For tolerances } 90.0-110.0 \%, \\
\text { number of points 9) }\end{array}$ & Conclusion \\
\hline $\mathrm{b} \pm\left(\mathrm{s}_{\mathrm{b}}\right)$ & $1.0122 \pm(0.0073)$ & - & - \\
\hline $\mathrm{a} \pm\left(\mathrm{s}_{\mathrm{a}}\right)$ & $-1.1938 \pm(0.7116)$ & $|\mathrm{a}| \leq \Delta \mathrm{a}=t(95 \% ; 7) \cdot \mathrm{S}_{\mathrm{a}}=1.348$ & corresponds \\
\hline $\mathrm{S}_{\mathrm{x}, 0}$ & 0.3859 & $\leq \Delta_{\mathrm{As}}(\%) / t(95 \% ; 7)=1.690$ & corresponds \\
\hline $\mathrm{r}$ & 0.9998 & $\geq 0.9555$ & corresponds \\
\hline
\end{tabular}

Table 4. Determination of the convergence of the quantitative determination results in intrauterine suppositories with trifusol

\begin{tabular}{|l|l|l|l|}
\hline $\bar{Z} \%$ & $\mathrm{~S}_{\mathrm{z}} \%$ & $\Delta \%$ & $\Delta$ As $\%$ \\
\hline 109.4 & 0.464 & 0.863 & 3.20 \\
\hline
\end{tabular}

Table 5. Determination of the correctness of the results of the quantitative determination of trifusol in intrauterine suppositories by the standard addition method

\begin{tabular}{|c|c|c|}
\hline Index & Criteria (For tolerances $90-110 \%$ ) & Value and conclusion \\
\hline Avg, $\bar{Z} \%$ & - & 99.88 \\
\hline Relative standard deviation, $\mathrm{S}_{\mathrm{Z}}, \%$ & $\leq 1.69$ & 0.519 Corresponds \\
\hline Relative confidence interval $\Delta \%=\mathrm{t}(95 \%, 8) \cdot \mathrm{S}_{\mathrm{z}} \%$ & $\leq 3.20$ & 0.965 Corresponds \\
\hline Systematic error $\delta_{\text {tot }}=|\bar{Z}-100|$ & - & 0.120 \\
\hline Criterion of insignificance of systematic error $\delta_{\text {tot }} \leq \Delta \% / 3$ & $\leq 0.322$ & Corresponds \\
\hline
\end{tabular}

$=0.9542$. The placebo contribution to the total absorption was $\delta_{\text {exc }}=100 \cdot 0.0031 / 0.9542=0.32 \%$ and was insignificant, because there is a ratio: $\delta_{\text {exc }} \leq 0.033 \cdot B=0.32 \leq 0.33$, therefore, the method had a sufficient specificity $[7,8]$.

Linearity for suppositories was determined within $73-127 \%$ of the nominal trifusol concentration. For this purpose was prepared a solution of suppository in purified water according to the method of quantitative determination of trifusol in veterinary effervescent suppository for intrauterine use, later it was used to obtain nine dilutions. The absorption of the obtained solutions at $278 \mathrm{~nm}$ was measured and a graph of the dependence of optical density

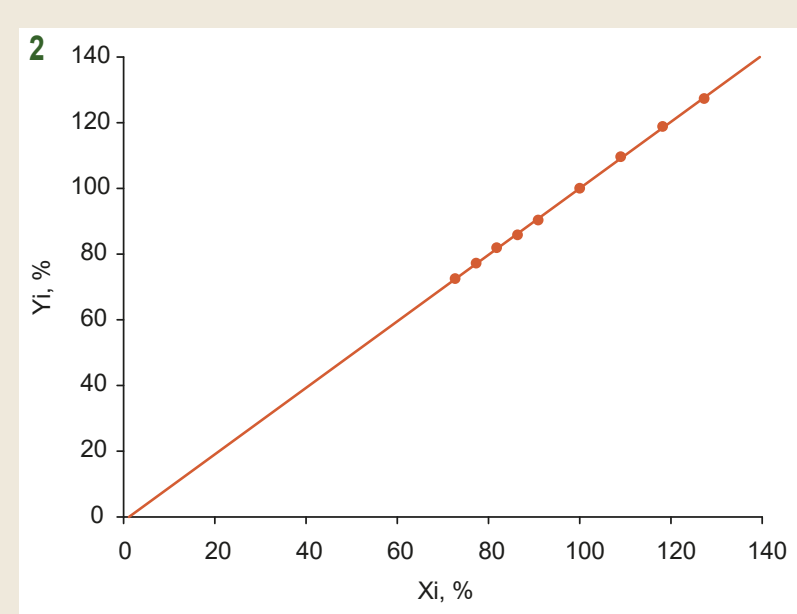

Fig. 2. Diagram of linear dependence of absorption on trifusol concentration in suppository. on the concentration of the studied substance in the sample was drawn up (Fig. 2, Table 3).

So, it was calculated numerical indicators testify that all requirements of the State Pharmacopoeia of Ukraine on parameters of linear dependence are fulfilled and linearity of a technique was confirmed in the chosen range of concentration [2-4].

To establish the accuracy of the technique nine parallel definitions (three weighed quantities of the studied drug form, three repetitions) were performed. The absorption of the comparison solution was measured simultaneously. The gram content of trifusol in the dosage form was calculated using a standard formula.

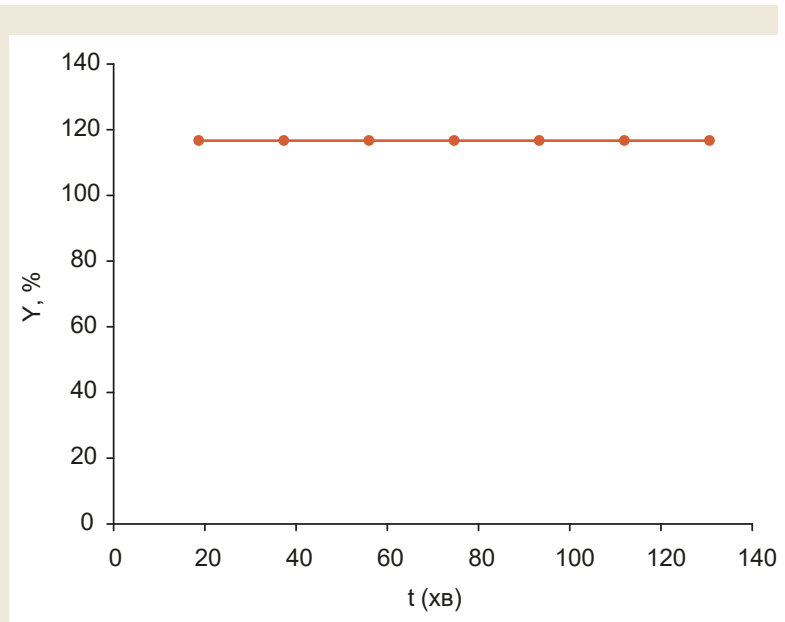

Fig. 3. Stability of the analyzed solution in time. 
According to the requirements of the State Pharmacopoeia of Ukraine, the one-sided confidence interval $(\Delta \%)$ should not exceed the maximum allowable uncertainty of the analysis $(\triangle A s \%)$. According to the State Pharmacopoeia of Ukraine, the deviation of the active substance content from the declared amount in the pessary (vaginal suppositories) was 90-110\% [3]. Thus, the maximum allowable uncertainty of the analysis $(\triangle A s \%$ ) was $3.20 \%$. Metrological characteristics were calculated based on the results: average value $\bar{Z} \%$, relative standard deviation $\left(\mathrm{S}_{\mathrm{Z}} \%\right)$, relative confidence interval $(\Delta \%$ ) (Table 4$)$.

The proposed methodology was accurate at the convergence level, as the one-sided confidence interval $\Delta \%$ did not exceed the maximum allowable uncertainty of the analysis $(\triangle A s \%)$.

To establish the correctness of the method, the standard addition method was used, in which different amounts of standard working solution of trifusol were added to three equal samples of the drug form and analysed three times.

According to the State Pharmacopoeia of Ukraine, the results of the definitions are correct if they are not burdened with a significant systematic error $\left(\delta_{\text {tot }}\right)$, i.e. the true value of the quantity to be determined falls within the specified confidence interval $(\Delta \%)$. Thus, the proposed method is correct because, as can be seen from Table 5, deviations $\bar{Z}$ from 100 $\%$ do not exceed their confidence interval [9].

The stability of solutions in time was studied to verify the robustness of quantitative determination methods. The tested solution and the comparison solution are stable for at least 60 min (Fig. 3).

\section{Conclusions}

A new sensitive, economic and express spectrophotometric method for quantitative determination of piperidinium 2-[5-(2-furyl)-4-phenyl-1,2,4-triasol-3-iltio]acetate in its dosage form - veterinary intrauterine effervescent suppository with its own absorption has been developed. The proposed method was validated and its compliance with the requirements of the State Pharmacopoeia of Ukraine was proved for the main validation characteristics: linearity, convergence, correctness and robustness.

Conflicts of interest: authors have no conflict of interest to declare. Конфрлікт інтересів: відсутній.

Information about the authors:

Klosova K. H., PhD-student of the Department of Clinical Pharmacy, Pharmacotherapy and MFE, Zaporizhzhia State Medical University, Ukraine.

ORCID ID: 0000-0001-6397-0029

Miedviedieva K. P., PhD, Senior Lecturer of the Department of Analytical Chemistry, Zaporizhzhia State Medical University, Ukraine.

ORCID ID: 0000-0001-7260-5728

Vasiuk S. O., PhD, DSc., Professor, Head of the Department of Analytical Chemistry, Zaporizhzhia State Medical University, Ukraine.

ORCID ID: 0000-0002-1569-9374

Bushuieva I. V., PhD, DSc, Professor of the Department of Clinical Pharmacy, Pharmacotherapy and MFE, Zaporizhzhia State Medical University, Ukraine.

ORCID ID: 0000-0002-5336-3900
Відомості про авторів:

Кльосова К. Г., PhD-аспірант каф. клінічної фрармації, фрармакотерапії та управління і економіки фрармації, Запорізький державний медичний університет, Україна.

Мєдвєдєва К. П., канд. фарм. наук, старший викладач каф.

аналітичної хімії, Запорізький державний медичний університет, Україна.

Васюк С. О., д-р фарм. наук, професор, зав. каф. аналітичної хімії, Запорізький державний медичний університет, Україна.

Бушуєва І. В., д-р фарм. наук, профресор каф. клінічної фрармації, фармакотерапії та управління і економіки фармації, Запорізький державний медичний університет, Україна.

Сведения об авторах:

Клесова К. Г., PhD-аспирант каф. клинической фармации, фармакотерапии и управления и экономики фармации, Запорожский государственный медицинский университет, Украина.

Медведева К. П., канд. фрарм. наук, старший преподаватель каф. аналитической химии, Запорожский государственный медицинский университет, Украина.

Васюк С. А., д-р фарм. наук, профессор, зав. каф. аналитической химии, Запорожский государственный медицинский университет, Украина.

Бушуева И. В., д-р фарм. наук, профессор каф. клинической фармации, фармакотерапии и управления и экономики фармации, Запорожский государственный медицинский университет, Украина.

References

[1] Parchenko, V. V. Panasenko, O. I., Knysh, Ye. H., Vasiuk, S. O., \& Tarkhanova, O. O. (2009). Yakisne ta kilkisne vyznachennia piperydynii 2-[5-(furan-2-il)-4-fenil-1,2,4-triazol-3-iltio]atsetatu v $1 \%$ ta $2,5 \%$ rozchynakh [Qualitative and quantitative determination of piperidine 2-[5-(furan-2-yl)-4-phenyl-1,2,4-triazol-3-ylthio] acetate in 1\% and $2.5 \%$ solutions]. Zaporozhye medical journal, 11(3), 111-113.

[2] State Enterprise Ukrainian Scientific Pharmacopoeial Center of Medicines Quality. (2014). Derzhavna Farmakopeia Ukrainy [The State Pharmacopoeia of Ukraine] $\left(2^{\text {nd }} \mathrm{ed}\right.$., Vol. 1). Kharkiv: Naukovo-ekspertnyi farmakopeinyi tsentr. [in Ukrainian].

[3] State Enterprise Ukrainian Scientific Pharmacopoeial Center of Medicines Quality. (2015). Derzhavna Farmakopeya Ukrayiny [The State Pharmacopoeia of Ukraine] $\left(2^{\text {nd }}\right.$ ed., Vol. 3). Kharkiv: State Enterprise Ukrainian Scientific Pharmacopoeial Center of Medicines Quality. [in Ukrainian].

[4] State Enterprise Ukrainian Scientific Pharmacopoeial Center of Medicines Quality. (2001). Derzhavna Farmakopeia Ukrainy [The State Pharmacopoeia of Ukraine] ( $1^{\text {nd }}$ ed., Add. 1-4.). Kharkiv: State Enterprise Ukrainian Scientific Pharmacopoeial Center of Medicines Quality. [in Ukrainian].

[5] Bushuieva, I. V., \& Klosova, K. H. (2019). Vnutrishnomatkovyi shypuchyi veterynarnyi supozytorii. Ukraine Patent UA 136849. Retrieved from https://base.uipv.org/searchINV/search.php?action=viewdetails\&IdClaim=261727 [in Ukrainian].

[6] Bushuieva, I. V., Knysh, Ye. H., Panasenko, O. I., \& Parchenko, V. V. (2014). Veterynarnyi supozytorii [Veterinary Suppository]. Ukraine Patent UA 92116. Retrieved from https://base.uipv.org/searchINV/ search. php?action=viewdetails\&IdClaim=203146 [in Ukrainian].

[7] Grisodub, A. I. (2016). Standartizovannyye protsedury validatsii metodik kontrolya kachestva lekarstvennykh sredstv [Standardized procedures for the validation of drug quality control methods]. Kharkiv: State Enterprise Ukrainian Scientific Pharmacopoeial Center of Medicines Quality. [in Russian].

[8] Grisodub, A. I., Zvolinskaya, N. N., Arhipova, N. N., Leont'ev, D. A. Denisenko, N. V. \& Dotsenko, T. N. (2004). Vosproizvodimost' farmakopeynykh spektrofotometricheskikh metodov kolichestvennogo opredeleniya lekarstv $v$ raznykh laboratoriyakh [Reproducibility of pharmacopeia spectrophotometric methods of quantitative determination of drugs in different laboratories]. Farmakom, (2), 20-34. [in Russian].

[9] Grisodub, A. I., Leont'ev, D. A., Denisenko N. N., \& Podpruzhynnikov, Yu. V. (2004). Standartizirovannyye protsedury dlya proverki metodov kontrolya kachestva lekarstvennykh sredstv $s$ ispol'zovaniyem standartnogo metoda [Standardized procedures for the validation of drug quality control methods using standard method]. Farmakom, (3), 3-14. [in Russian]. 